\title{
TANGGUNGJAWAB NEGARA TERHADAP KEBAKARAN HUTAN DAN LAHAN DALAM PERSPEKTIF HUKUM NASIONAL DAN ISLAM
}

\author{
Syafi'ul Anam', Muhammad Afdhal Askar²
}

${ }^{1}$ Sekolah Tinggi Agama Islam Negeri Bengkalis e-mail: Syafiulanam05@gmail.com

${ }^{2}$ Sekolah Tinggi Agama Islam Negeri Bengkalis e-mail: afdhalaskar05@gmail.com

\begin{tabular}{|l|l|l|}
\hline Diterima: 04-05--2020 & Direvisi: 16-05-2020 & Dipublish: 29-06-2020
\end{tabular}

\begin{abstract}
The responsibility given by the state to the occurrence of forest and land fires so far has not been considered optimal. Whereas the state has responsibilities towards its citizens, one of which is in ensuring the rights of citizens to get a clean and healthy environment. The liability referred to arises from the legal relations between the countries as mentioned in the fourth alinia of the Preamble of the 1945 Constitution through the phrase "protecting the entire Indonesian nation and the whole of Indonesian blood". Whereas in the Islamic perspective it also regulates that the purpose of the state is to create benefit for its citizens. Therefore, various losses to citizens due to forest and land fires should have been the responsibility of the state. So that what is demanded from the role of the State is not only prevention but also overcoming various impacts of losses caused as a result. Research is a normative juridical study using secondary data as the main. The nature of this research is qualitative.
\end{abstract}

Kata kunci: Tanggung jawab negara, kebakaran hutan, hukum nasional, Islam

\section{PENDAHULUAN}

Tualitas lingkungan hidup sangat mempengaruhi kelangsungan perikehidupan manusia dan makhluk hidup lainnya. Untuk itu perlu dilakukan perlindungan dan pengelolaan lingkungan hidup yang sungguh-sungguh dan konsisten oleh semua pemangku kepentingan. Oleh karena itu, eksistensi Undang-Undng No. 32 Tahun 2009 tentang Perlindungan dan Pengelolaan Lingkungan Hidup menjadi upaya sistematis dan terpadu yang dibentuk untuk melestarikan fungsi lingkungan hidup dan mencegah terjadinya pencemaran dan kerusakan lingkungan hidup.

Bila merujuk pada Pasal 65 ayat (1) Undang-Undang No. 32 Tahun 2009, dinyatakan bahwa setiap orang berhak atas lingkungan hidup yang baik dan sehat karena bagian dari Hak Asasi Manusia nya. Atas dasar tersebut, Negara mempunyai tanggung jawab yang tidak yang harus dilaksanakan. Hal ini sejalan dengan tujuan dibentuknya Negara Kesatuan Republik Indonesia sebagaimana yang tertuang dalam Alinia Keempat Pembukaan Undang-Undang Dasar Negara Kesatuan Republik Indonesia Tahun 1945 (selanjutnya disebut UUD 1945). Secara utuh disebutkan sebagai berikut:

"Kemudian daripada itu untuk membentuk suatu pemerintah Negara Indonesia yang Melindungi segenap bangsa Indonesia dan seluruh tumpah darah Indonesia dan untuk memajukan kesejahteraan umum, mencerdas- 
kan kehidupan bangsa dan ikut melaksanakan ketertiban dunia yang berdasarkan kemerdekaan, perdamaian abadi dan keadilan sosial, maka disusunlah kemerdekaan kebangsaan Indonesia itu dalam siatu undangundang dasar Negara Indonesia, yang terbentuk dalam suatu susunan Negara Republik Indonesia yang berkedailatan rakyat dengan berdasar kepada ketuhanan yang Maha Esa, kemanusiaan yang adil dan beradab, persatuan Indonesia dan kerakyatan yang di pimpin oleh hikmat kebijaksanaan dalam permusyawaratan/ perwakilan, serta dengan mewujudkan suatu keadilan sosial bagi seluruh rakyat Indonesia.

Namun demikian, adanya ketidakseimbangan lingkungan hidup menjadi permasalahan pada banyak negara maju dan berkembang. (Soerjani, 1987: 187) Ketidakseimbangan sebagaimana dimaksud diantaranya muncul akibat dari peristiwa kebakaran hutan dan lahan yang terjadi pada banyak daerah di Indonesia. Lebih spesifiknya, daerahdaerah tersebut seperti Provinsi Riau, Jambi, Sumatera Selatan, sebagian Kalimantan.

Selain ketidakseimbangan dalam lingkungan hidup, peristiwa kebakaran hutan dan lahan juga telah menimbulkan dampak dalam berbagai sektor kehidupan. Dampak tersebut seperti munculnya gangguan kesehatan secara meluas dalam masyarakat. Di samping itu, sektor lain yang terganggu di antaranya adalah ekonomi. Hal ini terjadi karena akibat mobilitas dan intensitas kegiatan masyarakat di luar ruangan yang juga menurun.

Namun dalam praktiknya, persoalan kebakaran hutan dan lahan terus terjadi setiap tahunnya namun belum dapat ditangani secara tuntas. Walaupun telah diterbitkan beberapa regulasi sebagai upaya pencegahan dan pengendalian kebakaran hutan dan lahan namun kejadian serupa terus saja terjadi bahkan dengan intensitas yang cendrung meningkat serta dampak kerusakan yang semakin meluas. Berlatar belakang hal ini, muncul berbagai gagasan untuk menuntut tanggung jawab Negara yang lebih luas dalam memberikan perlindungan hak-hak warga negara sebagai akibat dari dampak terjadinya peristiwa kebakaran hutan dan lahan baik yang terjadi akibat kelalaian/ kesengajaan manusia maupun karena peristiwa alam. Secara normatif, gagasan tersebut didasarkan atas Pembukaan dan bantang tubuh UUD 1945 serta peraturan perundang-undangan terkait lainnya. Lebih luasnya, tanggung jawab negara juga meliputi tanggung jawab dalam hal munculnya berbagai kerugian materil akibat dari peritiwa kebakaran hutan dan lahan tersebut. Apabila hal tersebut tidak dilaksanakan, maka warga negara sebagai pihak yang memiliki hubungan hukum dengan negara memiliki peluang hukum untuk melaksanakan tuntutan (gugatan) keperdataan terhadap negara.

Sulit dipungkiri, bahwa terus terjadinya peristiwa kebakaran hutan dan lahan adalah bentuk kegagalan pemerintah untuk memberikan perlindungan Hak Asasi Manusia warga negara berkaitan dengan hak untuk mendapatkan lingkungan yang bersih dan sehat. Artinya, perlindungan dan pengelolaan lingkungan hidup sejatinya dasar penghormatan terhadap berbagai jenis Hak Asasi Manusia (HAM). Perlindungan terhadap hak untuk mendapatkan lingkungan yang bersih dan sehat sendiri dimaksudkan untuk mencapai kualitas hidup manusia yang seutuhnya. Oleh karena itu, perlindungan atas hak untuk mendapatkan lingkungan hidup yang baik dan sehat harus dilakukan negara secara maksimal dan 


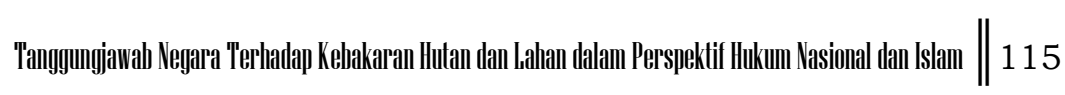

terhadap hal tersebut tidak dapat dapat dikurangi dalam kondisi dan alasan apapun apapun. (Masrudi Muchtar, Abdul Khair, 2016: 37)

Sejalan dengan itu, Islam sebagai agama mayoritas di Indonesia yang nilainilainya mempengaruihi sumber hukum materiil sangat menjunjung tinggi nilainilai kemanusiaan. Salah satu ajaran yang terkandung di dalamnya adalah mengatur tentang muamalah yaitu hubungan antara manusia dengan manusia. Kemanusiaan itu sendiri di artikan saling peduli, saling melindungi, saling membantu dan bekerja sama. Bahkan Al-Qur'an sendiri menjelaskan agar manusia untuk saling menolong, saling membantu, dan di larang berbuat kerusakan.

"Dan carilah apa yang telah dianugerahkan Allah kepadamu (kebahagiaan) negeri akhirat, dan janganlah kamu melupakan bahagianmu dari (kenikmatan) duniawi dan berbuat baiklah (kepada orang lain) sebagaimana Allah telah berbuat baik kepadamu. Dan janganlah kamu berbuat kerusakan di (muka) bumi. Sesungguhnya Allah tidak menyukai orangorang yang berbuat kerusakan". (Q.S. alQashash [28]: 77).

Atas dasar hal tersebut, maka adanya tanggung jawab negara terhadap terjadi-nya kebakaran hutan dan lahan dalam perspektif hukum nasional dan keislaman tidak dapat dikesampingkan. Hal itu merupakan konsekuensi dari hubungan hukum yang muncul antara Negara dan warga negara yang diikat melalui peraturan perundang-undangan yang pada pokoknya bertujuan untuk melindungi kepentingan dan hak-hak warga negara serta tujuan dari negara/ pemerintahan dalam perspektif Islam ada kemashalatan dan keadilan.

\section{METODE PENELITIAN}

Penulisan ini dilaksanakan dalam bentuk penelitian yuridis normatif yang merupakan penelitian hukum dengan mengkaji norma dan teori hukum yang relevan berdasarkan literatur hukum yang berkembang. Sebagai penelitian yuridis normatif, penelitian ini semata-mata hanya meneliti permasalahan yang terjadi dalam tataran norma dan teori hukum tanpa secara langsung mengkaji data-data yang bersifat secara empiris. Sebagai penelitian yuridis normatif, maka jenis data yang digunakan dalam penelitian ini adalah data sekunder yang bersumber dari bahan hukum primer, bahan hukum sekunder, dan bahan hukum sekunder. Bahan hukum primer adalah bahan hukum yang bersumber dari peraturan perundang-undangan yang terkait dengan fokus kajian penelitian sedangkan bahan hukum sekunder adalah bahan hukum yang menjelaskan bahan hukum primer seperti buku-buku, jurnal, hasil-hasil penelitian artikel dan lain. Bahan hukum sekunder adalah bahan hukum yang memberikan penjelasan terhadap bahan hukum primer dan bahan hukum sekunder seeprti Kamus Besar Bahasa Indonesia (KBBI), kamus bahasa asing, dan kamus hukum. Penulisan ini bersifat deskriptif yang merupakan pemaparan atau gambaran dari hasil penelitian yang ditemui dari elaborasi berbagai litaratur dan peraturan perundang-undangan yang kemudian akan dituangkan dalam bentuk karya tulis. 


\section{TANGGUNG JAWAB NEGARA TERHADAP KEBAKARAN HUTAN DAN LAHAN DALAM PERSPEKTIF HUKUM NASIONAL.}

Pasal 1 ayat (3) UUD 1945 telah menyatakan bahwa, Indonesia adalah negara hukum. Dalam konsep negara hukum, semua manusia akan mendapat perlakuan dan kedudukan yang sama dalam hukum, sosial, ekonomi, dan kebudayaan. (Didi Nazmi, 1992: 50) Atas perlakuan dan kedudukan yang sama tersebut maka setiap penyelenggaraan Negara harus berdasarkan aturan yang berlaku, menghindari kesewenangwenangan (arbitarypower) berupa penyalahgunaan kekuasaan (misuse of power) dengan memperhatikan prinsip lainnya seperti asas legalitas, peradilan yang bebas serta perlindungan terhadap hak asasi manusia.

Atas dasar hal itu, melalui amandemen kedua UUD 1945 diatur seacara lebih luas kewajiban negara dalam memberikan perlidungan Hak Asasi Manusia bagi warga negara. Salah satunya adalah perlindungan bagi lingkungan hidup (ecocracy) yang baik dan sehat. Ketentuan tersebut dapat dijumpai dalam Pasal 28 H ayat (1) UUD 1945 menyatakan bahwa, "Setiap orang berhak hidup sejahtera lahir dan batin, bertempat tinggal, dan mendapatkan lingkungan hidup yang baik dan sehat serta berhak memperoleh pelayanan kesehatan". Melalui norma hukum ini, kewajiban negara dalam memberikan jaminan terhadap lingkungan hidup yang bersih dan sehat bagi warga negara selanjutnya diatur dalam berbagai perangkat peraturan perundang-undangan lainnya di Indonesia.

Pertama, Undang-Undang No. 39 Tahun 1999 tentang Hak Asasi Manusia mengawali pemberian jaminan atas perlindungan bagi lingkungan yang baik dan sehat bagi seluruh warga. Hal tersebut dapat ditemui dalam Pasal 9 ayat (3) yang memerintahkan negara untuk menjamin hak bagi warga negara agar mendapat lingkungan hidup yang baik dan sehat. Oleh karena itu, kemudian muncul persepsi baru bahwa jaminan terhadap terwujudnya lingkungan yang baik dan sehat adalah bagian perlindungan Hak Asasi Manusia dalam konteks lingkungan dan kesehatan. Bahkan, sebagai bagian dari Hak Asasi Manusia maka hak tersebut sejatinya tidak hanya menjadi hak bagi warga negara Indonesia saja, melainkan juga hak bagi warga negara asing. (Asshiddiqie, 2012: 385)

Selanjutnya di Tahun 2009 lahir UU No. 32 Tahun 2009 tentang Perlindungan dan Pengelolaan Lingkungan Hidup. Undang-Undang ini sendiri sejatinya merupakan bagian dari upaya sistematis dan terpadu untuk melestarikan fungsi lingkungan hidup dan mencegah terjadinya pencemaran dan kerusakan lingkungan hidup itu sendiri. Pasal 1 angka (2) menjelaskan upaya-upaya tersebut meliputi perencanaan, pemanfaatan, pengendalian, pemeliharaan, pengawasan, dan penegakan hukum. Oleh karena bagian dari Hak Asasi Manusia maka setiap orang berhak mendapatkan pendidikan, lingkungan hidup, akses informasi, akses partisipasi, dan akses keadilan dalam memenuhi hak atas lingkungan hidup yang baik dan sehat. Menariknya dalam Undang-Undang ini diatur tentang beberapa langkah penegakan hukum berkaitan dengan perlindungan lingkungan hidup. Langkah-langkah tersebut diantaranya dengan mengajukan gugatan ke pengadilan dan selanjutnya ke tahap 
pembuktian dan melaksanakan keputusan dari hasil persidangan.

Lebih lanjut, UU No. 32 tahun 2009 Pasal 13 menjelaskan perihal tanggungjawab Negara terhadap terjadinya kebakaran hutan dan lahan yang mengakibatkan terganggunya hak-hak warga negara untuk mendapatkan lingkungan yang baik dan sehat. Pasal tersebut berbunyi:

"Pengendalian pencemaran dan/atau kerusakan lingkungan hidup dilaksanakan dalam rangka pelestarian fungsi lingkungan hidup. Pengendalian tersebut meliputi pencegahan, penanggulangan dan pemulihan. dan pengendalian tersebut dilaksanakan oleh pemerintah, pemerintah daerah, penanggung jawab usaha dan/atau kegiatan sesuai kewenangan, peran dan tanggung jawab masing-masing". Berdasarkan ketentuan ini, atas peristiwa kebakaran hutan dan lahan yang mengakibatkan terjadinya pencemaran dan atau kerusakan lingkungan hidup juga secara tegas menyatakan tidak bisa mengenyampingkan tanggung jawab negara.

Perihal tanggung jawab Negara terhadap kebakaran hutan dan lahan dan perlindungan terhadap lingkungan bersih dan sehat di atur juga dalam UU No. 18 Tahun 2013 tentang Pencegahan dan Pemberantasan Perusakan Hutan. Pasal 2 huruf c secara utuh menyebutkan:

Pencegahan dan pemberantasan perusakan hutan berasaskan:
a. Keadilan;
b. Keberlanjutan
c. Tanggung jawab negara;
d. Partisipsi masyarakat;
e. Tanggung gugat
f. Prioritas; dan
g. Keterpaduan dan koordinasi

Merujuk pada Penjelasan Pasal 2 huruf c UU No. 18 Tahun 2013, tanggung jawab negara sendiri bermakna pencegahan dan pemberantasan perusakan hutan merupakan tanggung jawab negara untuk melakukannya agar kelestarian hutan tetap terjaga. Secara luas, hal ini bertujuan untuk menjamin terwujudnya lingkungan yang baik dan sehat bagi warga negara dengan memperhatikan partisipasi masyarakat dalam berbagai hal lainnya. Dimana partisipasi tersebut harus juga berikan perlindungan untuk tidak dituntut secara pidana maupun digugat secara perdata. (Sembiring, 2017: 3)

Dalam konteks Negara hukum, norma-norma di atas memunculkan keterikatan/ hubungan hukum antara antara negara dan warga negara. Dalam perspektif yang jarang di sorot, sejatinya ada kewajiban (prestasi) yang harus dilaksanakan oleh Negara untuk menghadirkan lingkungan yang baik dan sehat. Teori negara berdasarkan atas hukum (de rechts staat dan the rule of law) yang mengandung tidak ada kekuasaan di atas hukum (above to the law), maka negara bertanggung jawab untuk melaksanakan norma-norma hukum yang tersebut. (Afnawi, 2013: 15)

Dalam perspektif keperdataan, maka norma-norma hukum di atas dapat dilihat sebagai sebuah kontrak/ perjanjian. Sederhananya perjanjian dapat dimaknai sebagai bahwa hubungan hukum antara pihak yang saling mengikatkan diri untuk melaksanakan suatu prestasi (perbuatan tertentu sesuai dengan yang telah disepakati (Subekti, 1987: 29) Sehingga bila salah satu pihak lalai/ tidak melaksanakan prestasi, maka pihak lain dapat menuntut haknya agar 
pihak yang lain memenuhi kewajiban/ prestasinya. (Muhammad, 1990: 17). Hal ini disebabkan karena salah satu tujuan dari pertanggungjawaban perdata adalah sebagai hukuman. (Wibisana, 2017: 1-3)

Lebih lanjut, prestasi tersebut hakikatnya berupa penghormatan hak atas lingkungan hidup yang baik dan sehat. Nilai universal Hak Asasi Manusia yang kemudian diterjemahkan dalam berbagai produk hukum nasional, dimaksudkan untuk melindungi dan menegakkan nilai-nilai kemanusian. Bahkan nilai universal ini dikukuhkan dalam instrumen internasional, termasuk perjanjian internasional di bidang Hak Asasi Manusia. (Masrudi Muchtar, Abdul Khair, 2016: 37) Berdasarkan paparan di atas maka dapat dipahami bahwa dalam pemberian jaminan adanya lingkungan hidup yang baik dan sehat harus diberikan Negara tanpa alasan apapun. Terjadinya kebakaran hutan dan lahan baik karena kesengajaan/ kelalaian manusia, faktor alam atau alasan lain tidak mengenyampingkan tanggungjawab Negara sebagaimana dimaksud. Pertanggungjawaban Negara terhadap peristiwa tersebut harus tetap dilaksanakan baik atas tuntutan (gugatan) masyarakat (warga Negara) ataupun karena kesadaran moril pemerintah selaku organisasi penyelenggara Negara.

Secara empiris, terjadinya kebakaran hutan dan lahan di negara Indonesia telah menimbulkan banyak dampak yang sangat dirasakan kerugiannya bagi masyarakat. Hal kerugian tersebut seperti pencemaran udara, gangguan kesehatan sampai dengan merosotnya ekonomi yang terjadi secara meluas. Bila negara belum mampu melaksanakan tanggung jawab tersebut maka muncul peluang masyarakat untuk melakukan berbagai upaya hukum baik termasuk bersifat keperdataan. Hal ini sejalan dengan tanggung jawab yang diartikan sebagai keadaan wajib menanggung segala sesuatunya jika terjadi apa-apa, boleh dituntut, dipersalahkan, diperkarakan atau juga berarti hak yang berfungsi menerima pembebanan sebagai akibat sikapnya oleh pihak lain. (Pusat Bahasa Departemen Pendidikan Nasional, 2008: 1443)

Hanya saja, upaya hukum yang bersifat keperdataan tersebut secara normatif telah ditutup oleh Mahkamah Agung melalui Keputusan Ketua Mahkamah Agung No. 36/KMA/SK/II/2013 Tentang Pemberlakuan Pedoman Penanganan Perkara Lingkungan Hidup. Keputusan tersebut menentukan bahwa gugatan yang dilakulan oleh masyarakat (warga Negara) hanya terbatas terbatas pada permohonan dilakukanya/ dihentikanya perbuatan tertentu, dan tidak boleh adanya permintaan ganti rugi yang bersifat keperdataan. Termasuk yang tidak dibolehkan dalam gugatan tersebut adalah pembatalan peraturan perundang-undangan, dan Pembatalan Surat Keputusan Tata Usaha Negara yang masing-masingnya adalah kewenangan dari Mahkamah Konstitusi dan/ atau Mahkamah Agung.

\section{TANGGUNG JAWAB NEGARA TERHADAP PENANGGULANGAN KEBAKARAN HUTAN DAN LAHAN DALAM PERSPEKTIF ISLAM}

Dalam mengatur masalah duniawi, Islam juga mengatur urusan dalam bernegara. Sebab Islam bukan hanya mengatur secara individu saja namun juga mengajarkan bagaimana bentuk kepedulian kaum muslimin dalam segala urusan yang bersangkutan dengan kepentingan dan kemashlahatan bersama, mengetahui apa yang diberlakukan 
penguasa terhadap rakyat, serta menjadi pencegah adanya kedzaliman.

Imam Ghazali pernah berkata, "Agama dan negara tidak bisa dipisahkan, agama adalah pondasi sedangkan pemerintahan adalah penjaga". Di lain kesempatan Ibn Taimiyah juga berpendapat bahwa mengatur urusan umat adalah kewajiban dari kehidupan beragama. (Muhammad Iqbal, 2013: 31) Islam dan pemerintahan adalah dua hal yang saling berkaitan. Sehingga kehadiran birokrasi dalam bingkai Islam menjadikan arah pemerintahan yang bisa mengayomi, memelihara dan mengatur segala lini kehidupan dengan berkeadilan dan mensejahterakan rakyatnya.

Terkait dengan tanggung jawab negara dalam tinjauan hukum Islam dapat dipedomani beberapa sumber hukum dalam agama Islam. Diantaranya AlQur'an dan Hadits yang menjelaskan mengenai tanggung jawab negara terhadap rakyatnya secara umum dan juga pada fiqh siyasah di karenakan belum menemukan referensi yang mengatur khusus tentang tanggung jawab negara.

Istilah negara atau pemerintahan sendiri dalam pandangan Islam disamakan dengan siyasah syar'iyah. Abdul Khalaf mendefinisikan siyasah syar'iyah sebagai pengelolaan masalah umum bagi pemerintahan Islam yang menjamin terciptanya kemashlahatan dan terhindarnya kemudharatan dari masyarakat Islam. (Iqbal, 2014: 5) Dari hal tersebut dapat dipahami bahwa negara atau pemerintah dalam Islam berkaitan dengan pengurusan dan pengaturan kehidupan manusia dalam pelaksanaan tugas pemerintahan di masyarakat sesuai dengan syari'at Islam untuk menciptakan kemashlahatan dan menolak kemudharatan.

Hal yang sama diungkapkan oleh Rifyal Ka'bah dengan menjelaskan bahwa pemerintahan Islam adalah bagian dari sistem pemerintahan yang memegang amanah Khalifah Allah dimuka bumi. Tujuannya adalah untuk menjalankan Syari'ah, menegakkan keadilan, menghapus kedzaliman, dan menjadikan masyarakat tertib, aman adil dan makmur. (Ka'bah, 2005: 114) Oleh karena itu, Al-Qur'an sebagai way of life memberikan gambaran tentang bagaimana seharusnya negara dalam hal ini pemerintah menjalankan kekuasaaNya. Allah SWT berfirman: (Kementerian Agama RI, 2010: 87)

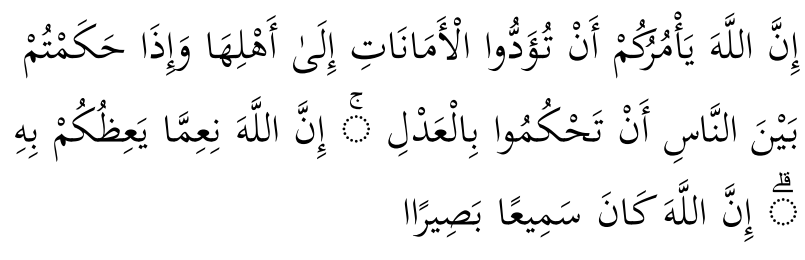

"Sesungguhnya Allah menyuruhmu menyampaikan amanat kepada yang berhak menerimanya, dan apabila kamu menetapkan hukum di antara manusia hendaknya kamu menetapkan dengan seadil-adilnya. Sungguh Allah sebaik-baik memberi pengajaran kepadamu. Sungguh, Allah maha mendengar lagi maha melihat." (Q.S an-Nisa [4]: 58)

Perihal amanah dalam ayat tersebut, Abdullah bin Muhammad dalam tafsir Ibnu Katsir mencakup seluruh amanah yang wajib bagi manusia. Baik berupa amanah kepada Allah maupun amanah terhadap hamba Allah, serta menetapkan hukum dengan seadil-adilnya. (A. Bin Muhammad, 2006: 336)

Di sisi lain dalam kaidah fiqh prinsip tanggung jawab negara dalam fiqh siyasah sesuai dengan tujuan Negara Islam yaitu 
untuk menciptakan kemaslahatan. Dalam kaidah fiqh di sebutkan:

$$
\begin{aligned}
& \text { درء المفاسد اولى من جلب المصالح debih di } \\
& \text { "Menghindari bahaya harus leiha } \\
& \text { utamakan dari meraih manfaat" }
\end{aligned}
$$

Dalam kaidah fiqh yang lain juga di sebutkan:

$$
\text { الخصلحة العامة مقدمة على المصلحة }
$$

"Kemaslahatan umum yang lebih luas harus diutamakan atas kemaslahatan yang khusus (golongan atau kelompok tertentu)"

Atas dasar kaidah-kaidah tersebut, dapat disimpulkan bahwa Islam memandang tanggung jawab negara hakikatnya adalah untuk melindungi kemaslahatan masyarakat yang lebih luas serta menciptakan kemaslahatan masyarakat. Maka dalam fiqh siyasah negara mempunyai tanggung jawab penting untuk merealisasikan tujuan tersebut. Negara harus mengenyampingkan/ membatalkan segala perihal yang tidak mendatangkan kemashalatan bagi warga negara. Sekiranya Negara telah mem-bangun hubungan hukum antara Negara dan warga Negara dengan melahirkan hak dan kewajiban melalui berbagai regulasi yang maka pihak-pihak yang ada dalam hubungan hukum tersebut sama-sama berkewajiban untuk melaksanakan tanggungjawabnya. Bila salah satu/ masing-masing pihak tidak dapat melaksanakan kewajibannya, maka pihak lain seharusnya bisa menuntut atas tanggungjawab yang dilaksanakan itu.

$$
\text { Keputusan Ketua Mahkamah }
$$
Agung No. 36/KMA/SK/II/ 2013 Tentang Pemberlakuan Pedoman Penanganan Perkara Lingkungan Hidup, dalam konteks kaidah fiqih di atas, tentu belum sepenuhnya mengandung nilai-nilai kemaslahatan. Padahal dalam peristiwa kebakaran hutan dan lahan kerugian yang ditanggung oleh masyarakat juga meliputi kerugian materil. Gangguan kesehatan mengharuskan memunculkan biaya pengobatan yang harus ditanggung masyarakat. Di sisi lain, terganggunya sektor ekonomi membuat penghasilan masyarakat juga menurun. Begitupun dengan kerugian-kerugian materil lainnya akibat terjadinya kecelakaan, kesalahan kerja dan lain sebagainya.

Dalam kepemimpinan Islam, tanggungjawab Negara pernah dicontohkan oleh Khalifah Umar Bin Khattab. Sebagai seorang pemimpin Umar Bin Khattab adalah sosok yang sangat sederhana, adil, dan begitu ramah kepada rakyatnya dengan berempati pada penderitaan dan kesusahan yang dirasakan oleh rakyat. Seperti pada saat Madinah dilanda oleh musim paceklik yang panjang yang mengakibatkan banyak rakyat madinah yang meninggal akibat kelaparan.

Melihat hal tersebut, Umar Bin Khattab merasa sedih dan terus membantu rakyatnya dengan memberikan sebagian besar hartanya. Bahkan, umar pun enggan memakan daging dan meminum susu hingga cobaan tersebut berlalu. Beliau justru hanya mengkonsumsi roti dan minyak zaitun saja agar dia bisa memahami bagaimana penderitaan yang di alami oleh rakyatnya yang kelaparan. Bahkan Umar gemar melakukan blusukan keliling kota untuk melihat kondisi rakyatnya dan membantu kesusahan yang di alami rakyatnya. Amirul mukminin tersebut menyadari bahwa ia sebagai pemimpin harus bertanggung jawab atas kondisi yang di alami rakyatnya. 
Dari kisah tersebut dapat diambil hikmah bahwa seorang pemimpin (Negara) tak bisa lepas dari tanggungjawabnya dalam kondisi apapun. Negara harus turun langsung mengatasi berbagai persoalan yang dihadapi oleh masyarakat. Berbagai upaya perlu dilakukan untuk menanggulangi persoalan tersebut termasuk dengan mensedekahkan harta pribadi demi menanggulangi dampak dari persoalan yang dihadapi masyarakat.

Bila diselaraskan dengan penanggulangan dampak akibat kebakaran hutan dan lahan yang terus terjadi setiap tahunnya di Indonesia, maka tanggungjawab yang diberikan Negara masih di rasa sangat minim. Penggulangan dampak yang dilakukan Negara baru sebatas penanggulangan kebakaran dan pengembalian fungsi lahan namun belum memperhatikan kerugian ekonomi yang disebabkan berkurangnya aktifitas dan menurunnya daya beli masyarakat, biaya pengobatan akibat timbulnya berbagai gangguan kesehatan, serta kerugiankerugian materil berupa kerusakan terhadap berbagai asset masyarakat karena berbagai peristiwa lanjutan seperti kecelakaan lalulintas dan kerja serta lain sebagainya.

\section{KESIMPULAN}

Dalam perspektif hukum nasional, Negara memiliki tanggungjawab terhadap terjadinya peristiwa kebakaran hutan dan lahan baik yang terjadi karena kesengajaan/ kelalaian manusia maupun karena peristiwa alam semata. Hal ini lahir dari adanya hubungan hukum antara Negara dan warga negara yang diikat oleh peraturan perundang-undangan di mana
Negara berkewajiban memberikan perlindungan bagi setiap warga negara untuk mendapatkan lingkungan hidup yang bersih dan sehat yang merupakan bagian dari Hak Asasi Manusia. Bila perlindungan tersebut tidak dapat diberikan, atas dasar hubungan hukum yang terbentuk melalui peraturan perundangundangan tersebut maka masyarakat (warga negara) seharusnya memiliki peluang hukum untuk melakukan tuntutan atas setiap kerugian yang diderita oleh masyarakat (warga negara) termasuk tuntutan dalam bentuk gugatan keperdataan untuk mengembalikan kerugian yang tanggung oleh masyarakat akibat peristiwa terebut. Di sisi lain, dalam perspektif hukum islam juga menuntut tanggungjawab negara terhadap terjadinya peristiwa kebakaran hutan dan lahan. Hal ini sesuai dengan dalil-dalil Al-Quran, Hadist, serta kaidahkaidah fiqih serta keteladanan dari sahabat Umar Bin Khatab selaku amirul mukminin, yang pada pokoknya menerangkan bahwa fungsi dari sebuah negara atau pemerintahan adalah pengaturan kehidupan manusia untuk menciptakan kemashlahatan dan menolak kemudharatan. Di samping itu tujuan dari pemerintahan Islam adalah untuk menjalankan Syari'ah, menegakkan keadilan, menghapus kedzaliman, dan menjadikan masyarakat tertib, aman adil dan makmur. Oleh karena itu, maka seharusnya peraturan perundanganundangan maupun peraturan lainnya sebagai hukum positif di Indonesia dapat secara lebih tegas mengatur pemberian perlindungan bagi warga Negara tidak hanya berkaitan dengan hak untuk memperoleh lingkungan yang bersih dan 
sehat tetapi juga pemulihan dari berbagai kerugian materil akibat terjadinya peristiwa kebakaran hutan dan lahan.

\section{DAFTAR PUSTAKA}

Afnawi, A. (2013). Hubungan Presiden Dengan Jaksa Agung Dalam Ketatanegaraan Indonesia Terkait Dengan Independensi Jaksa Agung. Universita Islam Negeri sunan kalijaga.

Asshiddiqie, J. (2012). Pengantar Ilmu Hukum Tata Negara. Jakarta: Rajawali Pers.

Iqbal, M. (2014). Fiqh Siyasah; Konstektualisasi Doktrin Politik Islam. Jakarta: Kencana.

Ka'bah, R. (2005). Politik dan Hukum dalam Al-Qur'an. Jakarta: Khairul Bayan.

Kementerian Agama RI. (2010). Al-Qur'an Tajwid dan Terjemahan. Jakarta: Sygma Exagrafika.

Masrudi Muchtar, Abdul Khair, N. (2016). Hukum Kesehatan Lingkungan. Yogyakarta.

Muhammad, A. K. (1990). Hukum Perikatan. Bandung: Citra Adtya Bakti.
Muhammad, A. Bin. (2006). Tafsir Ibnu Katsir. Bogor: Pustaka Imam Syafi'i.

Muhammad Iqbal, A. H. N. (2013). Pemikiran Politik Islam. Jakarta: Prenada Media Group.

Nazmi, D. (1992). Konsepsi Negara Hukum. Padang: Angkasa Rayas.

Pusat Bahasa Departemen Pendidikan Nasional. (2008). Kamus Besar Bahasa Indonesia. Jakarta: Departemen Pendidikan Nasional.

Sembiring, R. (2017). Menyoal Pengaturan Anti Eco-SLAPP Dalam UndangUndang Nomor 32 Tahun 2009. Jurnal Hukum Lingkungan, 3.

Soerjani, M. (1987). Lingkungan: Sumber Daya Alam dan Kependudukan dalam Pembangunan. Jakarta: Universitas Indonesia.

Subekti. (1987). Hukum Perjanjian. Jakarta: PT Inermasa.

Wibisana, A. (2017). Penegakan Hukum Lingkungan melalui pertanggungjawaban Perdata. Depok: BP-FHUI. 